\title{
SUNDA'S LOCAL ASSISTANCE IN LEADERSHIP
}

\author{
Kunkunrat $^{1}$, Ade Priangani ${ }^{2}$, Ika Sri Hastuti ${ }^{3}$, Rasman Sonjaya ${ }^{4}$ \\ 1,2,3 International Relations Universitas Pasundan, Indonesia \\ ${ }^{4}$ Communication Science Universitas Pasundan, Indonesia \\ ${ }^{1}$ kunkunrat@unpas.ac.id, ${ }^{2}$ ade.priangani@roketmail.com, ${ }^{3}$ isrihastuti@gmail.com, \\ ${ }^{4}$ rasman.sonjaya@unpas.ac.id
}

\begin{abstract}
Leadership is a way of influencing the running of social institutions and institutions so that they can run according to the goals of mutually agreed values. In Sundanese culture there are guidelines for leading which are recorded in ancient texts that guide the Sundanese kings. In today's modern era, leadership is faced with disrupted and evolving changes. This article discusses how the local values of Sundanese leadership are facing rapid changes. The writing method uses a literature review from journals and articles related to Sundanese leadership using descriptive analysis, namely explaining the concepts, values and style of Sundanese leadership. The results of the data analysis conducted show that the values of the leadership concept based on the "parigeuing" leader guidelines are still relevant to the current modern era of leadership. Sundanese local values such as Animan (gentle), Ahiman (firm), Mahiman (broad-minded, Lagiman (agile/agile/skilled), Prapti (right on target), Prakamya (tenacious/diligent), Isitwa (honest), Wasitwa (open to criticism). Sundanese leadership is like a teacher and santri, it takes a smart and knowledgeable (knowledgeable) leader, then the teacher will delegate all contents to the santri. The history of the conquest of Sunda by Mataram caused fragments of past history, the accumulation of values, and the psychological structure that we inherit from the past that settles in the collective consciousness of the Sundanese people, who sometimes don't believe themselves to appear and are sitting backward.
\end{abstract}

\section{Keywords: Local Wisdom, Leadership, Sundanese}

\section{Introduction}

Humans and culture are one of the bonds that cannot be separated in this life. Humans as God's most perfect creatures create their own culture and preserve it from generation to generation. Culture is created from daily activities and also from events that have been arranged by the Almighty. In addition, humans are social creatures who interact with each other and carry out certain habits which eventually become the culture they usually do. Culture is a product of man, but man himself is a product of culture. In other words, culture exists because humans created it and humans can live in the midst of the culture they created. Culture will continue to live when there are humans as residents and culture has enormous uses for humans in their lives.(Saleh3, 2019)
Culture is an integrated whole in which there are elements of culture from all humans wherever they are. Koentjaraningrat compiled seven elements of culture that are universal based on the opinion of anthropologists. The seven elements of culture in question are:

a. Language.

b. Knowledge system.

c. Social organization.

d. Live equipment systems and technology.

e. Live livelihood system.

f. Rreligious system.

g. Art system.(Sumarto, 2018)

Koenjtaraningrat in Warsito, the form of culture is divided into three parts, namely:

1) The form of culture as a complex of ideas, ideas, values, norms, rules, and so on. 
2) The form of culture as a complex of patterned activities and actions of humans in society.

3) The form of culture in the form of objects made by humans. (Warsito, 2012)

Indonesia as a multicultural country is faced with globalization which changes the way and view of Indonesian people in overcoming global challenges. However, this does not forget the history that produces cultural forms such as ancient manuscripts (buhun) which have become the guidelines for people's lives in the past as local wisdom is still relevant to be implemented today.

According to the perspective of the Indonesian-English dictionary, local wisdom consists of two domains, namely wisdom and local. Wisdom means wisdom and local means local. Thus, the notion of Local Wisdom is values, ideas, full of wisdom, wise local views, good values that are embedded and obeyed by community members. Another understanding of local wisdom is that it is part of the community's culture that cannot be separated from the language of the community. Local wisdom is generally passed on by word of mouth. Local wisdom exists in folk tales, songs, proverbs, and folk games. Local wisdom is knowledge obtained by the presence of certain local residents through a collection of experiences in experiments and integrated into an understanding of the culture and natural conditions of a place.

Local wisdom is explicit knowledge that comes from a long time and develops along with the community and environment in the region based on experience. Therefore it can be said that local wisdom in each region depends on the needs of life and the environment, including politics and leadership.

Politics is present-day history and history is past politics. History provides data and facts for politics while politics provides theory for history. History without political science has no fruit; political without history has no root (history without political science is like a fruitless tree; politics without history is like a tree without roots), says Sir Robert Seeley.
In today's era of globalization, examining the history and local wisdom of past cultures is a wise attitude, because if we look carefully, without realizing it, there are many benefits and cultural information resulting from creativity and legacy of previous karuhun (ancestral heritage) that can be extracted and revealed. in the present. (Charliyan, 2013).

One of them is digesting local wisdom that is buried in the cultural treasures of ancestors' heritage. Especially with to regard leadership issues. Local wisdom in Sundanese leadership is written in the ancient Sanghyang Siksakandang Karesian (SSK) manuscript, which contains the life guidelines for the Sundanese people. Local wisdom in leadership is known as "parigeuing" (Rangga Saptya Mohamad Permana, Elis Suryani Nani Sumarlina, 2020)

Since being known through historical records, it is known that the Sundanese people know the tradition of power, including leadership. In the political history of the archipelago, the Tarumanagara Kingdom was one of the oldest known kingdoms located in the West Java area.

From the manuscript of Pustaka Pararatwani Bhumi Jawadwipa, it is known that the kingdom was established for approximately 3 centuries (4th century to 7 th century) and there have been around 12 changes of kings (leaders). The peak period of Tarumanagara's heyday occurred during the time of King Purnawarman (394-434). The last Tarumanagara king, Linggawarman, had a son-in-law named Tarusbawa. Tarusbawa is then known as the founder and first king of the Sundanese kingdom which ruled for approximately 54 years (669-723) (Rosidi, 2011).

The Kingdom of Sunda itself collapsed in 1579 due to a joint attack by Banten and Cirebon which was expanding Islamic influence. The existence of the Tarumanagara Kingdom and the Sunda Kingdom (Galuh, Pakuan Padjadjaran and Sumedang Larang) proves that since the beginning of AD the Sundanese people have recognized a long and stable tradition of 
power and political tradition. Therefore it can be said that if the tradition of power is measured by the existence of the Sundanese kingdom, then the Sundanese political experience has lasted for about 14 centuries or more.

Since the rule of the Sundanese kingdom was wiped out by Islamic influence (17th century), Sundanese political history has relatively had no continuation. The dominance of the Sundanese kingdom was replaced by the Islamic kingdoms of Cirebon and Banten. After independence, the legacy of Sundanese ideology and values of power does not find its reflection in the history of the modern Indonesian state. The 20 years of the Old Order era and the 32 years of the New Order, as indicated by Benedict Anderson (1990) and Fachry Ali (1986), are reflections and manifestations of Javanese rule of thought. Sundanese culture has hardly inherited the values of power (automatically leadership) in modern Indonesian politics.(As-Sundani, 2019)

Besides that, there are difficulties in finding local heritage or wisdom in the Sundanese leadership, because before the Padjajaran kingdom, the culture of reading and writing and pouring events in the form of books had not become a habit, while after the Padjajaran kingdom, the Sundanese leadership did not find a place to be implemented, because after the domination Padjajaran by Cirebon and Banten, then under the rule of Mataram, then Dutch colonialism, and independence to become part of Indonesia, there was no opportunity to apply the Sundanese leadership model.

Thus the only era, where leadership found the realm of power and politics, combined with the written culture that was already owned was the period of the Padjajaran kingdom. So the reference to ancient Sundanese refers to that period. One of the products at that time was an ancient manuscript written in palm leaves, which contained a Sundanese encyclopedia in the 15 th century and previously was the Sanghiyang Siksa Kandang Karesian script.(Salam, 2017)

\section{Method}

The research method used is a qualitative method, namely research procedures that utilize descriptive data, in the form of written or spoken words from people and actors who can be observed. Qualitative research is conducted to explain and analyze phenomena, events, social dynamics, attitudes, beliefs, and perceptions of a person or group towards something. This article uses literature review data from various journals, newspaper articles and books related to the topics discussed by carrying out the stages of data analysis analysis starting from the data collection stage, data reduction and categorization, data display, and drawing conclusions. Qualitative data analysis is integrated into the activities of data collection, data reduction, data presentation, and conclusion of research results.

The method that uses the Systematic Literature Review is the literature method of identifying, assessing, and interpreting all the findings on a research topic, to answer research questions that have been previously determined (Kitchenham \& Charters, 2007). This method is used to analyze Sundanese leadership as a keyword in collecting relevant secondary data from journal articles.

\section{Result and Discussion}

Sundanese local wisdom about leadership is written in the script of Sanghyang Siksa Kandang Karesian, when discussing about power, it has been longer than that, to be precise during the Tarumanagara Kingdom, and perhaps since the time of the Salakanagara kingdom (results of recent research, it is found that there is a kingdom that is older than Tarumanagara. and Kutai Kartanagara).

Even for the division of power in the trias politic model, as argued by Montesque, consisting of the Legislative, Executive and Judiciary, it has existed in Sundanese society since its primordial era. This can be read from the composition of Sundanese villages and Sundanese pantun. In the old Sundanese society, they did not believe that the power over society and the state (village) came from the realm of heaven (Kahiyangan). 
Humans get the mandate of power from Sunan Ambu Ratu Agung Pamuhunan (Ambu Luhur). Power is transcendent. In the village "Baduy Dalam", there is a unity of three large villages, namely Cikeusik, Cikertawana, and Cibeo. The power is held by the respective pu'un.

The power mandate from the heavenly world was given to the Cikeusik village. The customs and social ethics of the village are controlled by Cikeusik. Punten with Salaka Domas terraces is in this village area. This shows the special relationship this village has with the world of the hyangs. Living in this world cannot be separated from the transcendental realm which is beyond the limits of human capabilities. Although the normative mandate of power rests in this village, it does not carry out that mandate. $\mathrm{He}$ is the owner but not the user. Executing power was instead handed over to younger villages, namely Cikertawana (youngest) and Cibeo (eldest). Cikertawana is the executor of power whose task is to unite the entire village. Meanwhile, Cibeo's job is to protect and guard Cikertawana, his job is to guard the security. Of course, many martial arts experts who are immune to weapons are found in this village.(Sumarjo, 2010)

So the old Sundanese political triad is in the form of: "Owner of Power" or "holder of the mandate of power" (Cikeusik). It does not carry out its mandate, but is highly respected and obeyed its laws. Its function is the holder of transcendental luck. ("Mandate Owner"). Meanwhile, the executive is in Cikertawana. He who decides what should be and what is taboo ("User of the Mandate"). Meanwhile, the supervisor and protector of power is Cibeo. ("Custodian of the Mandate"). Both Cikertawana and Cibeo have great respect for Cikeusik. (Jacob, 2004)

In the management of the Sundanese kingdom, Trias Politika was known where the Maharaja of Tarusbawa himself as the prebu "leader of the central government wheel" supervised several regional rulers who were appointed by mutual agreement with the rama "community leaders, representatives of the people" and the receipt party "determinants of legal policies".
(Widyonugrahanto Widyonugrahanto, Nina Herlina Lubis, Mumuh Muhzin Z., Dede Mahzuni, Kunto Sofianto, R.M. Mulyadi, 2017)

The principle of such a division of three is still found in village communities today. Anthropological research by Robert Wessing on the village of Pameuntasan near Bandung found the division of functions of three main villages, namely: Kampung Gajah as the holder of pre-Islamic Sundanese customs (old graves and respected important relics are there); Kampung Ciseah as the holder of Islamic law; Kampung Pameuntasan itself is the holder of modern power (lurah, camat). This Trias Politika description can also be seen in the group of Pajajaran sons who are wandering in search of new territories. In Carita Guru Gantang, this young son of Siliwangi was accompanied by Patih Purwa Kalih, Gegedug Kidang Pananjung and Jaksa Gelap Nyawang. The three accompanying pieces represent trias politica. Prince Pajajaran is clearly the owner of the mandate of power from Sunan Ambu (King of Pajajaran), he is a perfect human or in the process of becoming a perfect human. The representative or Patih Putra Pajajaran in the journey is ua Purwa Kalih (Parawa Kalih, Perewa Kalih). Dark Nyawang is a prosecutor, the one who orders and decides everything in the odyssey. Kidang Pananjung is a gegedug or Panglima, namely pioneers of roads and eradicating obstacles in traveling. So: Purwa Kalih and Pangeran Pajajaran are analogous to Cikeusik (the owner of the mandate of power); Dark Nyawang with Cikertawana and Kidang Pananjung with Cibeo who is an expert in martial arts and war.

In the context of leadership, the Sundanese people refer to the ancient manuscript Sanghiyang Siksa Kandang Karesian (1518 AD) which records the behavior of King Jayadewata / Siliwangi, who died in 1512, about the accusation of etiquette to be a leader in society at that time. That offender is called Parigeuing a Parigeuing. Parigeuing mah narana: bisa nitah bisa miwarang, ja sabda arum wawangi, nya mana tidak surah di piwarang. (The whip of the parigeuing is that it can be ruled to be asked 
by a terrifying story to the point of not being irritated at the command).

In order to be able to carry out parigeuing, the methods must be carried out by implementing the Dasapasanta (Sapuluh panengtrem hate), among others: Guna is the person being ordered must understand the meaning being ordered; Ramah Orders conveyed must be reasonable and reasonable, friendly, feel his value as a human being; Hook/Hookeun (amazed), the orders given are a picture of admiration for his abilities; Pesok, Heart-captivating (reueus). So orders that are conveyed must be captivating, which give rise to pride in themselves which creates a sense of pride in themselves. Asih, namely compassion, considers itself part of the one giving orders. Take responsibility with pride; Karuni/ Karunya. it means that the command given is affection (pity) and also in the form of a gift of confidence in his ability; Mukpruk, meaning that it must be able to provide awareness, orders are part of the task, not compulsion; Ngulas, which means giving comments (reviews) of each servant's work sincerely and wise; Nyecep, which means being able to cool the mind which is given orders. Be it verbally or giving gifts; and, Ngala angen. That is, it can attract servant hoops. By establishing proper friendship, a sense of loyalty will emerge towards the leader.

Apart from the text above, the concept of leadership is also contained in the Sanghyang Hayu manuscript which is a nipah-based text from the XVI century AD. : Budi-Guna-pradana (Wise-Prudent-Saleh); Kaya-wak-ideal (healthy/strong hearted); Pratiwi-akasa-antara (earth-space-time; Mata-tutuk-talinga (sight-speech-hearing, and Bayu-sabda-hedap (energy-speech/ word of will/heart and mind). All are related to one another which build up the attitude and character of the ideal leader.(Suryani, 2010)

A good ideal leader, according to the script of Sanghyang Hayu, must adhere to the principle of astaguna "eight wisdoms" so that his leadership is harmonious, good, and harmonious. First, animan (gentle), the leader must have a gentle nature, in the sense of not behaving rudely; Second, ahiman (firm), being firm, in the sense of not being capricious (panceg haté); Third, mahiman (broad-minded), has various kinds of knowledge and has high insight so as not to lose to his subordinates. Fourth, lagiman (agile / nimble / skilled), demanded to be skilled and nimble and deft in acting or performing a job; Fifth, prapti (right on target), has the sharpness of thinking and is right on target because if it is wrong or speculates it will hinder a job; Sixth, the prakamya (tenacious / persevering), has very high tenacity and persistence; Seventh, isitna (honest), is required to have honesty, both in words, thoughts, and actions, so that it is trusted by other people (colleagues/ business/company/other countries) and their subordinates. Thus, a harmonious understanding is established; Eighth, the referee (open to criticism), has a friendly and wise attitude so that he is willing to accept suggestions and is open to criticism if he makes a mistake or deviates from the rules.

Sundanese leadership belongs to the transending totalitarian type of leadership. This type of leadership involves dialogue in the process of fusing values and expectations through indoctrination. Subordinates are described as being in the middle of an emergency situation that requires immediate decisions but subordinates are in confusion. So that the hierarchy of value priorities by leaders without compromising with followers. Leadership can be seen from the results. Sundanese leadership is included in the category of leadership that transforms entrepreneurship. We can find this in the elements led by some Sundanese leaders who are in a quite competitive situation so that, leaders who need to transform values that can be used in the competition. Then, the values that are transformed by leaders create independence for their adherent.(Surya, 2010)

Leadership is also seen from the source of power. Sundanese leadership is a charismatic transactional leadership type. Leadership like this in conveying ideas, ideas and values is accompanied by a dimension of self-image or the charm of the leader to instill an emotional element between the leader and followers. Therefore, 
a leader figure is a person who is meritorious or has advantages over his followers. For some conditions this can make it easier for the leader offer his ideas and followers more easily believe in the leader figure.

The interesting thing contained in the Sundanese leadership, namely nyalindung ka gelung, which basically means depending on others, has no attitude. The broad meaning of the expression nyalindung $k a$ gelung, does not want to try, relies on oneself to the income of the wife or in-laws. Nyalindung means taking refuge, surrendering, entrusting life to something or to someone because it is usually the wife who is coiled (which is curled) This meaning indicates that when the leadership of the husband or man does not work optimally, women actually have extraordinary abilities to maintain sustainability The leadership potential that is actually possessed by women, if given the opportunity, can make a significant contribution.

"How persistent the ancient Sundanese elders were in exploring what had happened in the long journey of our nation's history. And it was revealed through the insights in the way of life, a valuable legacy as a guide from the lowest leader to the highest leader. We start from family leaders. There is a proverb. gagade bari nyarande. Every parent must always yearn for his child to progress, far beyond the progress achieved by his parents. Said his father - ""Kilangbara atuh, bapa jadi patani, maneh mah kudu jadi pamingpin-"(Even if your father is a farmer, you must be a leader). The son replied, "Atuh, Pa. Piraku bapa ngongkosan abdi, ngaluarkeun ongkos langkung tina kabutuhan bapa. (Please, pa. (How could you finance me, spend more than your family's needs) Said his father, Keun bae bapa mah gagade bari nyarande ge, asal hidep bisa leuwih ti bapa".(It's okay, I can pawn while leaning, as long as you can be more than me) This is an example of leadership shown by a father family leaders will make sacrifices for the betterment of their children. A leader must be like that, he must be more concerned with welfare and progress. his men. (Iskandar, 2006)
Don't be a leader who "Nyalindung $k a$ Gelung". Depending on other people, it has no attitude. An example of the term haripeut ku teuteureuyeun is a description of greed. If you become a leader, don't be "haripeut $k u$ teuteureuyeun" meaning is don't be greedy, don't be corrupt or collusion. Then the term "Kejot Borosot" that expression means; a leader should not make quick or hasty decisions.

Phrases, terms, or proverbs, because if lived it turns out to have a deep meaning as a guide for life. The advice of the elders is carried out, carried out, the benefits and impacts will be felt, both for family leaders or for higher leaders. There are so many Sundanese phrases that can be used as guidelines for conceptualization, so that the Sundanese leadership remains based on the Sundanese philosophy.

In the book The Corporate Mystic: A Guidebook for Visionaries with Their Feet on The Ground by Gay Hendricks and Kate Ludeman (1996). According to Haji Hasan Mustapa, the tradition of Sundanese leadership is nyantri, nyakola and nyunda. First, leadership must have spiritual intelligence symbolized by the nomenclature of nyantri. Spirituality is a fixed price as the last bastion so that a leader is well aware that leadership is a mandate that must be accounted for. The nomenclature of the santri assumes a leader anchors every step in the light of religiosity so that he thinks a thousand times when he was about to commit a basilat (corruption). In the global era, governments and large companies that can survive are actually anchored in this key to the sensitivity of the queens (mystical dimension).(Salahudin, 2010)

Of course, we don't have to understand this queue as a form of accentuation of the application of formal religion in a narrow sense, but what is more important is how religious values become the direction of social ethics to be applied by everyone regardless of the affiliation of official religious institutions as by attracting the great philosopher Haji Hasan Mustapa. written in the title Hariring $\mathrm{Nu}$ Hudang Gering. It is even further explored that when these students only stop as a 'sign' of 
differentiating formality with abangan and priyayi, then actually at that time the qualifications of the santri will not say much if they do not take part in the tradition of corruption.

The following interesting interpretation of Haji Hasan Mustapa:

\section{Barodona alam nyantri \\ Tacan kitab tacan Quran \\ Tacan daraek masantren \\ Tacan agama drigama \\ Kaula era paradah \\ Sirung ngamomore dapur \\ Dapuran kamanusaan}

Of course, a leader must manage. Having sufficient reasoning so that what is said and becomes part of policy making is truly proportional to the public interest. Nyakola is not synonymous with academic degrees, it does not necessarily mean the strata of lecture levels, especially if an academic degree is obtained by means of a plagiarism defect. Nyakola is actually a symbol of someone who is more concerned with reason than body, reason that never stops thinking. Never think of mortgaging reason for a moment's sake, seeking power in a dishonorable way. The geneological tradition of knowledge is seen in Soekarno, Hatta, Tan Malaka, Agus Salim, Cokroaminoto, Natsir, and so on, so that the political space becomes busy with enlightening debates.

Nyunda as the third requirement does not have to be interpreted reductively as merely a geographic ethnic reference that refers to the Pasundan region, but nyunda is a diction with the meaning of a set of Sundanese values that must be possessed by leaders and prospective leaders. In essence, these values are inclusive, perennial local wisdom that is shared by other cultures.

Nyunda as an open culture can also be shared by those who are not geographically similar in place of birth. So the rational choice if we are faced with an option: choosing a Sundanese person who is not delayed or non-Sundanese but does not delay? Of course the calculation of public rationality will lead to the second choice.
Because nyunda is a cultural value and perennial wisdom, we should, if anything, contest the claim that someone's Sundanese leader is just speaking Sundanese with his head shackled by iket while his actions are far from being burned with Sundanese values.

Nyunda actually reflects, among other things, the figure of a leader who is able to merge with the people sincerely (ngumawula ka wayahna), pribadi nu teu ningkah (does not act); teu adigung kamagungan (not arrogant and shows an arrogant attitude towards others); teu paya diagreng-agreng (doesn't like to be enlivened with pomp); nyaah kanu masakat (loving the poor); agung maklum sarta adil (wise and fair); landung kandungan, laer aisan (has a broad perspective) and cadu basilat (impossible corruption).

For the Sundanese, finding a leader always seems very difficult. This is more due to the culture and the wrong interpretation of religious texts which they consider to be an integral part of the "urang Sunda" cultural values, so what was born later was a leadership crisis that led to the inferiority of Sundanese people in their association at the national level.

What is the historical root of the Sundanese leadership crisis? This question is absolutely put forward not to judge the past, considering that as a West Javanese society we live in a fragment of history and are part of that history, but rather to describe a reality that moves dynamically in our consciousness, being able to control the pace of history through the structure of consciousness.

In practical politics, the involvement of a person (a Sundanese) is more viewed as a personal matter that has nothing to do with the life and interests of the Sundanese people at a macro level. The involvement of an individual from the Sundanese community has never been seen as a representative of the entire community, as far as political issues are concerned. The political involvement of ordinary people (somah, outside the royal family link) in state affairs only occurred during the 
conquest (through marriage) of Mataram over Sunda. Many ordinary people had the opportunity to occupy strategic positions at that time.

This condition is described in the legend of Pun Boncel. The legend tells how a commoner's child (somah) became priyayi. However, this achievement, as described in the legend, is considered to have tarnished the sanctity of primordial values (symbolized by the mother): which is described as the refusal of children (the somah, who must obey instead of ruling) against the mother (primordial Sundanese values). ) This historical experience seems to have formed a sub-conscious area of the Sundanese people, thus giving birth to some political attitudes of the Sundanese people who tend to be passive. The events of political divisions in Sundanese history have become political traumas that are embedded in the subconscious of the Sundanese people, so they tend to always be suspicious of someone's involvement in the political and state arena. So that the Sundanese people tend to take a silent or passive attitude (not supportive and not showing opposition) towards certain individuals who are involved in political arenas, and tend to avoid conflict. This gave birth to an attitude of never looking positively at the involvement of somah (wong cilik) in the political arena and in state affairs. Because, political affairs are the affairs of the royal (family) not the affairs of the people. As evidence, let alone political issues (political leadership) on a national scale, even issues of political leadership on a regional scale rarely (not to say never) become the subject of serious discussion among the grassroots Sundanese people, except only as casual talk(Drs. Ahmad Gibson Al-Bustomi, 2011) The Sundanese people have the cultural characteristics expected by Islam, so it is not wrong if many people say that Sundanese culture is actually Islam which at the end point always says that Sundanese is Islam. Becoming Islam means relying all patterns of life on the Al Quran and the Prophet's Sunnah as a way of life, including in terms of leadership. We understand the proposition, "Do not ask for office", with the interpretation "may not" pursue leadership. Finally what we often see is the lack of echo of the Sundanese people to compete for good leadership at home, especially at home. the national scope. Sundanese people prefer not to join in and "mangga akang bae ka payun" rather than have to "sweat" to be the best. These things are very visible in the interaction between ethnic groups, military civilians, junior seniors, and so on.

Al Quran actually describes that leadership must be fought for. Because being a leader is a mandate, it must be supported by sufficient knowledge and clean track records. He must be able to protect, protect and preserve society and the environment properly and not allow what has been damaged to become more damaged.

According to Ibn Khladun, leadership based on ashobiyah has six characters. First, a leader must be knowledgeable with the ability to make decisions in accordance with the law. According to Ibn Khaldun, a leader must place the law as the main rule. $\mathrm{He}$ himself is not allowed to play and game the law; Second, he must be fair. This means being honest, holding on to justice, and having good moral qualities so that his words and actions can be trusted. Third, he has the ability to carry out the tasks required of him as a government leader, including implementing laws that are consequently decided.

Fourth, physically and mentally, he must be free from disabilities that do not allow him to carry out his duties as a good leader; Fifth, the leaders of a government must come from and be chosen from their own clan; Sixth, a leader must be gentle and polite towards his followers and must prioritize the interests of the people and must defend them and also not find fault with the people; These six theories of Ibn Khaldun are clear evidence in any leadership pattern, especially as a former government apparatus in his day; Ibn Khaldun once felt that community-supported leadership based on social solidarity and originating from his own ethnic group would be able to make his government strong.(Ilham, 2016)

The philosophy of leadership in every culture is customarily different from one another. Likewise in Sundanese society. 
Every leader must always yearn for his subordinates to progress, far beyond the progress achieved by the leader. Leadership shown by a female leader who dares to sacrifice for the advancement of his subordinates. This is symbolized in the phrase gagade bari nyarande.

A Sundanese proverb which means looking for support to support economic conditions which may be very mediocre. The leader must be like that, he must be more concerned with the welfare and progress of his subordinates

The public response to our leaders (read: the president) creates a unique pattern. We raised them with an optimistic spirit, but dropped them as a loser, if not called a bad person. Soekarno, who when appointed as president, the community supported him as a leader of rescue and freedom fighter. However, at the end of his reign, Soekarno was completely ignored by the Indonesian people, even in some history his death contained many mysteries and not many people know. Even more extreme, he was thought to be involved with the 30S PKI Movement in 1965.

Likewise with Soeharto who was cheered up during the moment of his appointment and was considered the savior of Pancasila from the PKI coup movement, but su'ul khatimah (ended tragically) at the end of his power by attaching various negative attributes to him. The phenomenon above strengthens a pattern of public perception of the rulers of our country or vice versa which tends to resemble the pioneer political model or also in Sundanese terms, Sakompet Daun politics. Coupled with the Regime's own fears of criticism of the people, some of these leaders practiced a hegemonic and dominant model of power such as Soekarno and Soeharto.

The people are easily lulled by the greatness and kindness of the leader, but it is the turn of the leader to make mistakes and the leader is easily turned into a culprit, as if all the destruction that happened to the leader did it. All its goodness has disappeared without a trace. In this model, society tends to generalize about problems that are not necessarily true. This is what I call sakompet daun its mean in general politics.

A historical event that has meaning for Sundanese political life is Pangeran Kornel, another nickname for Pangeran Kusumah Dinata, a historical figure who needs to be an example by us in his actions as a political or community leader. He was the son of the Sumedang regent named Raden Adipati Surianagara, and he was appointed as the Regent of Sumedang in 1791 with the title Tumengung Surianagara. As a regent he was known to be wise. During his reign, people's lives developed well and prosperously. He was also known as a capable and honest leader.

Ajip Rosidi (1985) describes him as a regent who succeeded in improving the lives of the Sumedang people. Even Nicolaas Engelhard (in Ajip Rosidi), a Dutch official, has testified that he is an honest regent. At that time, Nicolaas was inspecting coffee plantations throughout Priangan, he stopped at Sumedang and said that the area had progressed, even the areas where forests were originally had been transformed into paradise. The existence of a rich person never acts to increase his wealth by using his power and position.

In other respects, Prince Kornel was a brave man who was very concerned about the interests of the little people even though he had to deal with circumstances that threatened him. It was proven when he loudly protested Daendels as the Governor General of the Dutch East Indies who implemented his policy in making the Anyer-Bayuwangi highway, he was seen as having raped the existence of the people. Daendels, who was known as a marschalk, was highly respected and feared by every people at that time, especially since the road construction on the prince's rock (current name) was not finished due to the lack of personalities.

However, Daendels' fearsome fear did not occur thanks to the figure of the leader Prince Konel who was able to provide understanding to the Marschalk. Thanks to his expertise as a democratic leader, the people became free from Daendels' threats. 
This is a picture of Sundanese leadership which refers to the local wisdom of the Sundanese people.

This proves that indeed the local wisdom of a civilization will influence leadership, both in terms of leadership style, leadership management abilities, and community acceptance of leadership.

\section{Conclusion}

Contemplating local wisdom does not mean going back to the past or becoming a traditional society again, but looking for the pearls of the ancestors and using them as a guide for every step forward. Like traditional villages, doesn't our state or government also have pamali, have laws or rules of the game, just like the Sundanese people who have a different way or form of leadership from other communities. One of them is digesting the local wisdom hidden in the cultural treasures of the ancestors. Especially those related to leadership issues. Local wisdom in Sundanese leadership is written in the ancient Sanghyang Siksakandang Karesian (SSK) manuscript, which contains a way of life for the Sundanese people of local wisdom in leadership known as "parigeuing". which describes fifteen important elements that a leader must possess, which are summarized into five groups, namely: Budi-gunapradana (wisdom-wise-pious); Kaya-wakcita (healthy/strong-minded); Pratiwi-akasaantara (earth-space-between); Mata-tutuktalinga (sight-speech-hearing, and Bayusabda-hedap (speech-energy/words/heart and mind). Everything is related to each other which builds attitude and character ideal leader.

Nyunda actually reflects, among other things, the figure of a leader who is able to unite with the people sincerely (ngumawula ka wayahna) who does not do much (not acting); teu adigung kamagungan (not arrogant and showing a high attitude towards others); teu paya diagreng-agreng (does not like to be celebrated with grandeur); nyaah kanu masakat (loving the poor); Agung is well-informed and just (wise and fair); landung kandungan, laer aisan (has a broad perspective) and cadu basilat (impossible corruption).
Sundanese people have cultural characteristics that are expected by Islam, so it is not wrong if many people say that Sundanese culture is actually Islam which at the end point always says that Sunda is Islam. , including in terms of leadership. In practical politics, the involvement of a person (a Sundanese) is more viewed as a personal matter that has nothing to do with the life and interests of the Sundanese people at a macro level. The involvement of ordinary people in politics is considered to tarnish the sanctity of primordial values, because politics is a royal business. The events of political divisions in Sundanese history have become political traumas that are embedded in the subconscious of the Sundanese people, so they tend to always be suspicious of someone's involvement in the political and state arena. So that the Sundanese people tend to take a silent or passive attitude (not supportive and not showing opposition) towards certain individuals who are involved in political arenas, and tend to avoid conflict. The Sundanese people need firmness and confidence to emerge as leaders on a national and regional scale.

\section{References}

As-Sundani, S. I. J. S. (2019). FENOMENA MUNCULNYAISLAM SUNDA PROGRESIF TAHUN 1917-2017. In

A. Supianudin (Ed.), Sunda dalam Kontak Kebudayaan dan Peradaban Islam Dunia (p. 206). Fakultas Adab dan Humaniora UIN Sunan Gunung Djati. http://digilib.uinsgd.ac.id/38260/1/Sun da Dalam Kontak Kebudayaan dan Peradaban Islam Dunia.pdf

Charliyan, A. (2013). Kepemimpinan Nasional Berbasis Kearifan Lokal Menuju Masyarakat Yang Tatatentrem, Kertaraharja [Universitas Puangrimagalatung]. https://fdokumen.com/document/kepe mimpinan-nasional-berbasis-kearifanlokal-menuju-masyarakat-yangtatatentrem-562f97bf14ae5.html

Drs. Ahmad Gibson Al-Bustomi, M. A. (2011, September 8). Sikap Politik Masyarakat Sunda. Elasgary. https://elasgary.wordpress.com/2011/0 9/08/sikap-politik-masyarakat-sunda/ 
Ilham, M. (2016). KONSEP 'ASHABIYAH DALAM PEMIKIRAN POLITIK IBNU KHALDUN. Jurnal Politik Profetik, Vol. 4 No. http://journal.uinalauddin.ac.id/index.php/jpp/article/vi ew/2733

Iskandar, E. D. (2006). “Gagade Bari Nyarande, Falsafah Kepemimpinan (Keluarga) Sunda." Pikiran Rakyat.

Rangga Saptya Mohamad Permana, Elis Suryani Nani Sumarlina, U. A. D. (2020). Konsep "Parigeuing" dalam konteks kepemimpinan dan komunikasi politik berdasarkan naskah Sunda kuno. Jurnal Kajian Komunikasi, Vol. 8 No. https://jurnal.unpad.ac.id/jkk/article/vi ew/25671

Rosidi, A. (2011). "Urang Sunda di Lingkungan Indonesia. ” Universitas Padjadjaran.

Salahudin, A. (2010). Tradisi Kepemimpinan Sunda. Pikiran Rakyat, 30 kolom 2.

http://pustaka.unpad.ac.id/wpcontent/uploads/2010/05/pikiranrakyat -20100508-

tradisikepemimpinansunda.pdf

Salam, M. (2017). SANGHYANG SIKSA KANDANG KARESIAN.

Soekapoera.Co.Id. https://soekapoera.or.id/2017/04/02/sa nghyang-siksa-kandang-karesian/

Saleh3, M. R. A. S. (2019). MANUSIA DAN KEBUDAYAAN(MANUSIA DAN SEJARAH KEBUDAYAAN, MANUSIA DALAM KEANEKARAGAMAN BUDAYA DAN PERADABAN, MANUSIA DAN SUMBER PENGHIDUPAN). Tadbir Jurnal Manajemen Pendidikan Islam, Vol. 7 Nom, 154-165.

https://journal.iaingorontalo.ac.id/inde x.php/tjmpi/article/view/1125

Sumarjo, J. (2010). Sunda: Rasionalitas Budaya. Kelir.

Sumarto. (2018). Budaya, Pemahaman dan Penerapannya "Aspek Sistem Religi, Bahasa, Pengetahuan, Sosial, Keseninan dan Teknologi." Jurnal Literasiologi, Vol. 1 No. https://jurnal.literasikitaindonesia.com/ index.php/literasiologi/article/view/49

Surya, P. (2010). KEPEMIMPINAN

PEREMPUAN BERNILAI

\section{KESUNDAAN DI BIDANG}

PENDIDIKAN. Jurnal Manajemen

Pendidikan, Vol. 1 No., 64-77.

http://staffnew.uny.ac.id/upload/19811

1112009121001/penelitian/KEPEMIM

PINAN+WANITA+BERNILAI+KES

UNDAAN+DALAM+LEMBAGA+P

ENDIDIKAN.pdf

Suryani, E. (2010). Pemimpin Ideal Dalam Naskah Sunda. Pikiran Rakyat.

Warsito. (2012). Antopologi Budaya. Ombak.

Widyonugrahanto Widyonugrahanto, Nina Herlina Lubis, Mumuh Muhzin Z., Dede Mahzuni, Kunto Sofianto, R.M. Mulyadi, U. A. D. (2017). THE POLITICS OF THE SUNDANESE KINGDOM ADMINISTRATION IN KAWALI-GALUH. Paramita Historical Studies Journal, 27. https://journal.unnes.ac.id/nju/index.ph p/paramita/article/view/9187 